\title{
Erratum to: Antioxidant activity and peroxidase inhibition of Amazonian plants extracts traditionally used as anti-inflammatory
}

Fabiano de S. Vargas' ${ }^{1}$ Patricia D. O. Almeida ${ }^{1}$, Ana Paula A. de Boleti ${ }^{1}$, Maria M. Pereira ${ }^{1}$, Tatiane P. de Souza ${ }^{1}$, Marne C. de Vasconcellos' ${ }^{1}$ Cecilia Veronica Nunez ${ }^{2}$, Adrian M. Pohlit ${ }^{2}$ and Emerson S. Lima ${ }^{1 *}$

Following the publication of the original article [1] it was brought to our attention that one of the authors' names was incorrectly displayed on the website and PDF version of the article. At current, the author name appears as 'Fabiano S. de Vargas', whereas the name should appear correctly as Fabiano de S. Vargas. We apologise for any confusion caused.

\section{Author details \\ ${ }^{1}$ Faculdade de Ciências Farmacêuticas, Universidade Federal do Amazonas - UFAM, Rua Alexandre Amorim, 330, Bairro Aparecida, Cep: 69010-300 Manaus, Amazonas, Brazil. ${ }^{2}$ Coordenação de Tecnologia e Inovação-CoTI, Instituto Nacional de Pesquisas da Amazônia-INPA, Avenida André Araújo, Petrópolis, CEP: 69067375 Manaus, Amazonas, Brazil.}

Received: 5 April 2016 Accepted: 5 April 2016

Published online: 14 April 2016

\section{Reference}

1. De S. Vargas F et al. Antioxidant activity and peroxidase inhibition of Amazonian plants extracts traditionally used as anti-inflammatory. BMC Complement Altern Med. 2016:16:83.

* Correspondence: eslima@ufam.edu.br

${ }^{1}$ Faculdade de Ciências Farmacêuticas, Universidade Federal do Amazonas UFAM, Rua Alexandre Amorim, 330, Bairro Aparecida, Cep: 69010-300 Manaus, Amazonas, Brazil

Full list of author information is available at the end of the article
Submit your next manuscript to BioMed Central and we will help you at every step:

- We accept pre-submission inquiries

- Our selector tool helps you to find the most relevant journal

- We provide round the clock customer support

- Convenient online submission

- Thorough peer review

- Inclusion in PubMed and all major indexing services

- Maximum visibility for your research

Submit your manuscript at

www.biomedcentral.com/submit 